\title{
Changes in Physical Properties of Red Soils "Terre de Barre" in South of Togo Under Different Compost Application Doses
}

\author{
Alate Koffi-Kouma Akouete ${ }^{1}$, Mawussi Gbenonchi ${ }^{1,}$ *, Ayisah Kwasi Dzola ${ }^{2}$, Sanda Komla ${ }^{1}$ \\ ${ }^{1}$ Department of Soil Sciences, Laboratory of Research on Agroresources and Environmental Health, Higher Agronomy School, University of \\ Lome, Lome, Togo \\ ${ }^{2}$ Department of Phytotechny and Plant Breeding, Higher Agronomy School, University of Lome, Lome, Togo
}

Email address:

gmawussi@gmail.com (M. Gbenonchi)

${ }^{*}$ Corresponding author

To cite this article:

Alate Koffi-Kouma Akouete, Mawussi Gbenonchi, Ayisah Kwasi Dzola, Sanda Komla. Changes in Physical Properties of Red Soils "Terre de Barre" in South of Togo Under Different Compost Application Doses. American Journal of Environmental and Resource Economics. Vol. 4, No. 4, 2019, pp. 159-164. doi: 10.11648/j.ajere.20190404.17

Received: November 6, 2019; Accepted: December 7, 2019; Published: December 23, 2019

\begin{abstract}
This work deals with assessing the impact of compost of household waste and poultry manure on physical properties of red soils commonly called "Terre de barre" in southern Togo. Field experiments were conducted in coastal zone of Togo during four seasons of crops alternating tomato-maize-tomato- maize. Two types of composts were applied at doses of $0,10,20,30$ and $40 \mathrm{tha}^{-1}$ respectively. One of the composts was elaborated with $100 \%$ of household solid wastes and the other with $70 \%$ of household wastes mixed with $30 \%$ of poultry manure. On each plot, composts were incorporated into the soil depth layers of $0-15 \mathrm{~cm}$. Soil samples were randomly collected in surface layer $(0-15 \mathrm{~cm})$ from plots for measurement of organic matter content, bulk density, total porosity and moisture content. Soil water infiltration rates were measured in situ in the field using infiltration rate double ring cylinder. The results showed that composts affected the soil parameters studied. Soil bulk densities were reduced. However, organic matter content, total porosity, moisture retention and water infiltration rate increased with compost application doses increasing. Finally, it can be concluded that household waste compost has pronounced effects on the physical properties of red soils in southern Togo. Composting of household urban solid wastes will solve environmental problem and will contribute to improve soil quality and agricultural productivity.
\end{abstract}

Keywords: Household Waste Compost, Soil Physical Properties Improvement, Bulk Density, Porosity, Moisture Content, Water Infiltration

\section{Introduction}

In rural communities in Togo as everywhere in SubSaharan Africa countries, the main economic activity is farming. People are directly dependent on locally grown crops harvested food. Smallholder farmers produce mainly maize, tomato, cassava, yam and common beans as staple food. Poor soil fertility is one of the most limiting agricultural productivity factors in smallholder farms in SubSaharan Africa countries [1]. Farmers traditionally relied on long fallow periods to restore land fertility. However, population increasing has shortened the fallow periods and decreased the available agricultural land. Furthermore, farmers remove crop residues from the field and use them for feeding their livestock or as fuel to cook their food. Crops are grown continuously on poor fields. Indeed, soil physical properties deteriorate with change in land use. Especially with continuous cultivation, physical properties and productivity of many soils commonly decline due to decrease in organic matter content [2]. Many important soil processes take place in soil pores (the air or water filled spaces between particles) [3]. Long-term cultivation tends to lower total porosity because of a decrease in soil organic matter. Waterholding capacity which is an important indicator of soil physical fertility is the capacity of soil to store and supply water and air for plant growth [4]. 
The use of organic fertilizers as compost increases the soil organic carbon pool, improves the soil porosity, structure, moisture content and water infiltration rate, provides nutrients and enhances microbial activity $[5,6]$. On another side, production of household solid waste, possible source of compostable organic matter, causes the major environmental problems over all the country in Togo. Sadly, red soils fertility decreasing in south of Togo is a serious problem to agricultural productivity on a farmers' field-scale.

This work investigates the changes that occurred in physical properties of red soils commonly called "Terre de barre" in southern Togo under different levels of household wastes compost application. It will contribute to household waste management by composting and soil fertility improvement for sustainable agricultural productivity and environmental problem solving.

\section{Material and Methods}

Field experiments were conducted in coastal zone of Togo at the Teaching Research and Demonstration Farm of Agronomic School at University of Lome located in $6^{\circ} 10^{\prime} \mathrm{N}$, $1^{\circ} 10^{\prime} \mathrm{E}$; altitude $=19-60 \mathrm{~m}$. The soil type was a ferralsol locally called "Terre de barre" that developed from a continental deposit [7]. This soil is red, deep and suitable for almost all crops.

Two composts used were produced with $100 \%$ of household urban solid wastes collected from Agbalepedogan district in Lomé and with $70 \%$ of household wastes mixed with $30 \%$ of poultry manure. The field experiments were conducted during four seasons of crops alternating tomato-maize-tomato- maize. The composts were applied at the beginning of each crop season. The land was manually ploughed and divided into plots with plot area of $3.84 \mathrm{~m}^{2}(2.4 \mathrm{~m} \times 1.6 \mathrm{~m})$. Each plot was separated from the adjacent by $1 \mathrm{~m}$ interval while the replicates were separated by $1.5 \mathrm{~m}$ interval. The treatments were arranged in a randomized complete block design and replicated three times. There were nine treatments per block composed by $\mathrm{T} 0$ as the control treatment without any compost use, T1, T2, T3 and T4 as compost elaborated with $100 \%$ of household waste applied at doses of $10 \mathrm{t} \mathrm{ha}^{-1}, 20 \mathrm{tha}^{-1}, 30 \mathrm{t}$ $\mathrm{ha}^{-1}$ and $40 \mathrm{t} \mathrm{ha}^{-1}$ respectively, T5, T6, T7 and $\mathrm{T} 8$ as compost elaborated with $70 \%$ of household wastes mixed with $30 \%$ of poultry manure applied at doses of $10 \mathrm{t} \mathrm{ha}^{-1}, 20$ $\mathrm{t} \mathrm{ha}^{-1}, 30 \mathrm{t} \mathrm{ha}^{-1}$ and $40 \mathrm{t} \mathrm{ha}^{-1}$ respectively. On each plot, composts were incorporated into the soil depth layers of $0-$ $15 \mathrm{~cm}$.

The land had been cropped previously for many years. Prior to land preparation, a composite soil sample was taken from surface layer $(0-15 \mathrm{~cm})$ in the experimental site with an auger for the analysis of particle size distribution and organic matter content. At the end of harvest of each crop season, the soil samples were taken randomly in surface layer $(0-15 \mathrm{~cm})$ from each plot for physical properties characterization as well as soil moisture content, bulk density, total porosity and organic matter content. Soil water infiltration rates were measured in situ in the field using infiltration rate double ring cylinder.

The amount of organic carbon content was determined following the wet oxidation method of Walkley and Black [8] while organic matter was calculated by multiplying the organic carbon value by 1.724 based on the assumption that organic matter contains $58 \%$ organic carbon [9]. Bulk density was determined, using the core method as described by Anderson and Ingram [10], from undisturbed soil samples that were taken in soil surface layer $(0-15 \mathrm{~cm})$ with a steel cylinder of volume $100 \mathrm{~cm}^{3}$. It was measured after undisturbed soil samples drying at $105^{\circ} \mathrm{C}$. Total porosity, the percentage of bulk volume of soil not occupied by solid particles, was calculated from bulk density values and constant particle density value estimated to $2.6 \mathrm{~g} / \mathrm{cm}^{3}$ [11, 12]. Soil water infiltration rates were determined in the field using infiltration rate double ring cylinder method (inner and outer rings were 30 and $50 \mathrm{~cm}$ in diameter respectively and the height was $40 \mathrm{~cm}$ ) [13]. Soil moisture content was measured by gravimetric method based on weighing of the amount of water lost by drying oven at $105^{\circ} \mathrm{C}$ (lid removed) until constant mass is reached [14-16]. Gravimetric method refers to the measurement of soil water content by measuring the difference in weight between a soil sample before and after drying.

\section{Results and Discussion}

The particle size distribution analysis revealed that soil surface layer $(0-15 \mathrm{~cm})$ of experimental site was loamy sand (Table 1). Organic matter content, bulk density, total porosity, moisture retention and water infiltration rates of soil were significantly affected by compost application during the experiment $(\mathrm{p}<0.05)$ (Tables $2,3,4 \& 5)$. The high compost doses (20 tha $\mathrm{ha}^{-1}, 30 \mathrm{tha}^{-1}$ and $40 \mathrm{tha}^{-1}$, respectively) showed the maximum organic matter content, total porosity, soil moisture content and water infiltration rates compared to plots of control and $10 \mathrm{t} \mathrm{ha}^{-1}$. This observation explain that compost of organic material (household waste and poultry manure) improved soil organic matter content and physical properties significantly by reducing soil bulk density and increasing total porosity, moisture content and water infiltration rate (Tables 2, 3, $4 \& 5$ ). This indicates that soil physical properties improvement depending the amount of organic matter content. This observation was also deduced by previous studies [6, 17-19].

Table 1. Organic matter content and particle size distribution in soil surface layer $(0-15 \mathrm{~cm})$ before trials experimental.

\begin{tabular}{lllll}
\hline Organic matter (\%) & Sand (\%) & Silt (\%) & Clay (\%) & Textural class \\
\hline 1.09 & 79.39 & 14.82 & 5.57 & loamy sand \\
\hline
\end{tabular}


Table 2. Changes in surface layer $(0-15 \mathrm{~cm})$ of soil organic matter content and soil physical properties at the end of first crop season.

\begin{tabular}{llllll}
\hline Treatments & $\begin{array}{l}\text { Organic matter } \\
\text { content (\%) }\end{array}$ & Bulk density $\left(\mathbf{g} / \mathbf{c m}^{\mathbf{3}}\right)$ & Total Porosity (\%) & $\begin{array}{l}\text { Soil moisture content } \\
\mathbf{( \% )}\end{array}$ & $\begin{array}{l}\text { Water infiltration } \\
\text { rates }(\mathbf{m m} / \mathbf{h})\end{array}$ \\
\hline$\left(0 \mathrm{t} \mathrm{ha}^{-1}\right)=\mathrm{T} 0$ & $1.09 \pm 0.03$ & $1.59 \pm 0.01$ & $38.84 \pm 0.01$ & $10.2 \pm 0.03$ & $61 \pm 02$ \\
$\left(10 \mathrm{t} \mathrm{ha}^{-1}\right)=\mathrm{T} 1$ & $1.15 \pm 0.03$ & $1.57 \pm 0.01$ & $39.61 \pm 0.01$ & $11.5 \pm 0.03$ & $63 \pm 01$ \\
$\left(20 \mathrm{t} \mathrm{ha}^{-1}\right)=\mathrm{T} 2$ & $1.6 \pm 0.03$ & $1.54 \pm 0.03$ & $40.76 \pm 0.03$ & $12.02 \pm 0.03$ & $66 \pm 03$ \\
$\left(30 \mathrm{t} \mathrm{ha}^{-1}\right)=\mathrm{T} 3$ & $2.04 \pm 0.03$ & $1.48 \pm 0.02$ & $43.07 \pm 0.03$ & $13.1 \pm 0.03$ & $70 \pm 03$ \\
$\left(40 \mathrm{t} \mathrm{ha}^{-1}\right)=\mathrm{T} 4$ & $2.9 \pm 0.03$ & $1.41 \pm 0.03$ & $45.76 \pm 0.03$ & $13.9 \pm 0.01$ & $71 \pm 04$ \\
$\left(10 \mathrm{t} \mathrm{ha}^{-1}\right)=\mathrm{T} 5$ & $1.3 \pm 0.03$ & $1.55 \pm 0.03$ & $40.38 \pm 0.02$ & $11.8 \pm 0.02$ & $65 \pm 01$ \\
$\left(20 \mathrm{t} \mathrm{ha}^{-1}\right)=\mathrm{T} 6$ & $1.7 \pm 0.03$ & $1.52 \pm 0.02$ & $41.53 \pm 0.02$ & $12.6 \pm 0.02$ & $69 \pm 03$ \\
$\left(30 \mathrm{t} \mathrm{ha}^{-1}\right)=\mathrm{T} 7$ & $2.05 \pm 0.03$ & $1.46 \pm 0.03$ & $43.84 \pm 0.03$ & $13.7 \pm 0.01$ & $72 \pm 02$ \\
$\left(40 \mathrm{t} \mathrm{ha}^{-1}\right)=\mathrm{T} 8$ & $3.01 \pm 0.03$ & $1.39 \pm 0.02$ & $46.53 \pm 0.02$ & $14.05 \pm 0.02$ & $76 \pm 03$ \\
\hline
\end{tabular}

T0: control without any compost usage, T1, T2, T3 and T4: household waste compost applied at doses of $10 \mathrm{tha}^{-1}, 20 \mathrm{tha}^{-1}, 30 \mathrm{tha}^{-1}$, and $40 \mathrm{tha}^{-1}$ respectively; T5, T6, T7 and T8: compost elaborated with $70 \%$ household wastes mixed with $30 \%$ poultry manure applied at doses of $10 \mathrm{t} \mathrm{ha}^{-1}, 20 \mathrm{tha}^{-1}, 30 \mathrm{tha}^{-1}$ and $40 \mathrm{t}$ ha ${ }^{-1}$ respectively.

Table 3. Changes in surface layer $(0-15 \mathrm{~cm})$ of soil organic matter content and soil physical properties at the end of second crop season.

\begin{tabular}{llllll}
\hline Treatments & $\begin{array}{l}\text { Organic matter } \\
\text { content }(\mathbf{\%})\end{array}$ & Bulk density $\left(\mathbf{g} / \mathbf{c m}^{\mathbf{3}}\right)$ & Total Porosity (\%) & $\begin{array}{l}\text { Soil moisture content } \\
\mathbf{( \% )}\end{array}$ & $\begin{array}{l}\text { Water infiltration } \\
\text { rates }(\mathbf{m m} / \mathbf{h})\end{array}$ \\
\hline$\left(0 \mathrm{t} \mathrm{ha}^{-1}\right)=\mathrm{T} 0$ & $1.04 \pm 0.03$ & $1.61 \pm 0.01$ & $38.07 \pm 0.01$ & $10.04 \pm 0.03$ & $60 \pm 02$ \\
$\left(10 \mathrm{t} \mathrm{ha}^{-1}\right)=\mathrm{T} 1$ & $1.19 \pm 0.03$ & $1.55 \pm 0.01$ & $40.38 \pm 0.01$ & $11.8 \pm 0.03$ & $65 \pm 01$ \\
$\left(20 \mathrm{t} \mathrm{ha}^{-1}\right)=\mathrm{T} 2$ & $1.16 \pm 0.03$ & $1.52 \pm 0.03$ & $41.53 \pm 0.03$ & $12.12 \pm 0.03$ & $68 \pm 03$ \\
$\left(30 \mathrm{t} \mathrm{ha}^{-1}\right)=\mathrm{T} 3$ & $2.24 \pm 0.03$ & $1.45 \pm 0.02$ & $44.23 \pm 0.03$ & $13.3 \pm 0.03$ & $72 \pm 03$ \\
$\left(40 \mathrm{t} \mathrm{ha}^{-1}\right)=\mathrm{T} 4$ & $3.03 \pm 0.03$ & $1.38 \pm 0.03$ & $46.92 \pm 0.03$ & $14.02 \pm 0.01$ & $74 \pm 04$ \\
$\left(10 \mathrm{t} \mathrm{ha}^{-1}\right)=\mathrm{T} 5$ & $1.4 \pm 0.03$ & $1.50 \pm 0.03$ & $42.30 \pm 0.02$ & $12.05 \pm 0.02$ & $67 \pm 01$ \\
$\left(20 \mathrm{t} \mathrm{ha}^{-1}\right)=\mathrm{T} 6$ & $2.08 \pm 0.03$ & $1.47 \pm 0.02$ & $43.46 \pm 0.02$ & $12.9 \pm 0.02$ & $70 \pm 02$ \\
$\left(30 \mathrm{t} \mathrm{ha}^{-1}\right)=\mathrm{T} 7$ & $2.19 \pm 0.03$ & $1.40 \pm 0.03$ & $46.15 \pm 0.03$ & $13.8 \pm 0.01$ & $76 \pm 02$ \\
$\left(40 \mathrm{t} \mathrm{ha}^{-1}\right)=\mathrm{T} 8$ & $3.13 \pm 0.03$ & $1.31 \pm 0.02$ & $49.61 \pm 0.02$ & $14.18 \pm 0.02$ & $79 \pm 02$ \\
\hline
\end{tabular}

T0: control without any compost usage, T1, T2, T3 and T4: household waste compost applied at doses of $10 \mathrm{tha}^{-1}, 20 \mathrm{tha}^{-1}, 30 \mathrm{t} \mathrm{ha}^{-1}$, and $40 \mathrm{tha} \mathrm{t}^{-1}$ respectively; T5, T6, T7 and T8: compost elaborated with 70\% household wastes mixed with 30\% poultry manure applied at doses of $10 \mathrm{t} \mathrm{ha}^{-1}, 20 \mathrm{tha}^{-1}, 30 \mathrm{t} \mathrm{ha}^{-1}$ and $40 \mathrm{t}$ $\mathrm{ha}^{-1}$ respectively.

Table 4. Changes in surface layer $(0-15 \mathrm{~cm})$ of soil organic matter content and soil physical properties at the end of third crop season.

\begin{tabular}{llllll}
\hline Treatments & $\begin{array}{l}\text { Organic matter } \\
\text { content (\%) }\end{array}$ & Bulk density $\left(\mathbf{g} / \mathbf{c m}^{3}\right)$ & Total Porosity (\%) & $\begin{array}{l}\text { Soil moisture content } \\
\mathbf{( \% )}\end{array}$ & $\begin{array}{l}\text { Water infiltration } \\
\text { rates }(\mathbf{m m} / \mathbf{h})\end{array}$ \\
\hline$\left(0 \mathrm{t} \mathrm{ha}^{-1}\right)=\mathrm{T} 0$ & $1.01 \pm 0.03$ & $1.62 \pm 0.01$ & $37.69 \pm 0.02$ & $10.02 \pm 0.03$ & $59 \pm 01$ \\
$\left(10 \mathrm{t} \mathrm{ha}^{-1}\right)=\mathrm{T} 1$ & $1.22 \pm 0.03$ & $1.53 \pm 0.02$ & $41.15 \pm 0.01$ & $12.02 \pm 0.03$ & $66 \pm 02$ \\
$\left(20 \mathrm{t} \mathrm{h}^{-1}\right)=\mathrm{T} 2$ & $1.23 \pm 0.03$ & $1.49 \pm 0.03$ & $42.69 \pm 0.03$ & $12.88 \pm 0.03$ & $71 \pm 03$ \\
$\left(30 \mathrm{t} \mathrm{ha}^{-1}\right)=\mathrm{T} 3$ & $2.44 \pm 0.03$ & $1.41 \pm 0.02$ & $45.76 \pm 0.03$ & $13.93 \pm 0.03$ & $75 \pm 03$ \\
$\left(40 \mathrm{t} \mathrm{ha}^{-1}\right)=\mathrm{T} 4$ & $3.17 \pm 0.03$ & $1.36 \pm 0.03$ & $47.69 \pm 0.02$ & $14.66 \pm 0.01$ & $77 \pm 04$ \\
$\left(10 \mathrm{t} \mathrm{ha}^{-1}\right)=\mathrm{T} 5$ & $1.46 \pm 0.03$ & $1.50 \pm 0.03$ & $42.30 \pm 0.02$ & $12.55 \pm 0.02$ & $69 \pm 01$ \\
$\left(20 \mathrm{t} \mathrm{ha}^{-1}\right)=\mathrm{T} 6$ & $2.29 \pm 0.03$ & $1.46 \pm 0.02$ & $43.84 \pm 0.02$ & $13.09 \pm 0.02$ & $73 \pm 02$ \\
$\left(30 \mathrm{t} \mathrm{ha}^{-1}\right)=\mathrm{T} 7$ & $2.35 \pm 0.03$ & $1.37 \pm 0.03$ & $47.30 \pm 0.03$ & $14.03 \pm 0.01$ & $80 \pm 02$ \\
$\left(40 \mathrm{t} \mathrm{ha}^{-1}\right)=\mathrm{T} 8$ & $3.39 \pm 0.03$ & $1.29 \pm 0.02$ & $50.38 \pm 0.02$ & $14.98 \pm 0.02$ & $87 \pm 03$ \\
\hline
\end{tabular}

T0: control without any compost usage, T1, T2, T3 and T4: household waste compost applied at doses of $10 \mathrm{tha}^{-1}, 20 \mathrm{tha}^{-1}, 30 \mathrm{tha}^{-1}$, and $40 \mathrm{t} \mathrm{ha} \mathrm{C}^{-1}$ respectively; T5, T6, T7 and T8: compost elaborated with $70 \%$ household wastes mixed with $30 \%$ poultry manure applied at doses of $10 \mathrm{tha}^{-1}, 20 \mathrm{tha}^{-1}, 30 \mathrm{tha}^{-1}$ and $40 \mathrm{t}$ ha ${ }^{-1}$ respectively.

Table 5. Changes in surface layer $(0-15 \mathrm{~cm})$ of soil organic matter content and soil physical properties at the end of fourth crop season.

\begin{tabular}{llllll}
\hline Treatments & $\begin{array}{l}\text { Organic matter } \\
\text { content }(\mathbf{\%})\end{array}$ & Bulk density $\left(\mathbf{g} / \mathbf{c m}^{\mathbf{3}}\right)$ & Total Porosity (\%) & $\begin{array}{l}\text { Soil moisture content } \\
\mathbf{( \% )}\end{array}$ & $\begin{array}{l}\text { Water infiltration } \\
\text { rates }(\mathbf{m m} / \mathbf{h})\end{array}$ \\
\hline$\left(0 \mathrm{t} \mathrm{ha}^{-1}\right)=\mathrm{T} 0$ & $0.97 \pm 0.02$ & $1.64 \pm 0.02$ & $36.92 \pm 0.01$ & $9.09 \pm 0.03$ & $57 \pm 03$ \\
$\left(10 \mathrm{t} \mathrm{ha}^{-1}\right)=\mathrm{T} 1$ & $1.25 \pm 0.02$ & $1.50 \pm 0.03$ & $42.30 \pm 0.03$ & $13.05 \pm 0.02$ & $69 \pm 01$ \\
$\left(20 \mathrm{t} \mathrm{ha}^{-1}\right)=\mathrm{T} 2$ & $1.28 \pm 0.03$ & $1.41 \pm 0.01$ & $45.76 \pm 0.02$ & $13.73 \pm 0.03$ & $76 \pm 02$ \\
$\left(30 \mathrm{t} \mathrm{ha}^{-1}\right)=\mathrm{T} 3$ & $2.49 \pm 0.02$ & $1.35 \pm 0.03$ & $48.07 \pm 0.03$ & $14.53 \pm 0.03$ & $78 \pm 01$ \\
$\left(40 \mathrm{t} \mathrm{ha}^{-1}\right)=\mathrm{T} 4$ & $3.27 \pm 0.01$ & $1.28 \pm 0.02$ & $50.76 \pm 0.01$ & $14.96 \pm 0.02$ & $80 \pm 04$ \\
$\left(10 \mathrm{t} \mathrm{ha}^{-1}\right)=\mathrm{T} 5$ & $1.49 \pm 0.01$ & $1.45 \pm 0.01$ & $44.23 \pm 0.02$ & $13.65 \pm 0.03$ & $73 \pm 02$ \\
$\left(20 \mathrm{t} \mathrm{ha}^{-1}\right)=\mathrm{T} 6$ & $2.31 \pm 0.02$ & $1.39 \pm 0.01$ & $46.53 \pm 0.02$ & $13.91 \pm 0.03$ & $77 \pm 03$ \\
$\left(30 \mathrm{t} \mathrm{ha}^{-1}\right)=\mathrm{T} 7$ & $2.41 \pm 0.01$ & $1.31 \pm 0.02$ & $49.61 \pm 0.01$ & $14.89 \pm 0.02$ & $87 \pm 03$ \\
$\left(40 \mathrm{t} \mathrm{ha}^{-1}\right)=\mathrm{T} 8$ & $3.59 \pm 0.02$ & $1.21 \pm 0.03$ & $53.46 \pm 0.01$ & $15.18 \pm 0.01$ & $94 \pm 01$ \\
\hline
\end{tabular}

T0: control without any compost usage, T1, T2, T3 and T4: household waste compost applied at doses of $10 \mathrm{tha}^{-1}, 20 \mathrm{tha}^{-1}, 30 \mathrm{tha}^{-1}$, and $40 \mathrm{t} \mathrm{ha}^{-1}$ respectively; $^{-1}$ T5, T6, T7 and T8: compost elaborated with 70\% household wastes mixed with $30 \%$ poultry manure applied at doses of $10 \mathrm{tha}^{-1}, 20 \mathrm{t} \mathrm{ha}^{-1}, 30 \mathrm{t} \mathrm{ha}^{-1}$ and $40 \mathrm{t}$ ha ${ }^{-1}$ respectively. 


\subsection{Organic Matter Content}

As shown in Tables 2, 3, 4 \& 5, considerable improvement in soil organic matter content was occurred with the application of composted organic material (household waste and poultry manure). These results indicated that the application of $20 \mathrm{t} \mathrm{ha}^{-1}, 30 \mathrm{tha}^{-1}$, and $40 \mathrm{tha}^{-1}$ compost of household wastes improved better the soil organic matter content when compared with control and $10 \mathrm{tha}^{-1}$. The higher organic matter content values recorded in plots received $20 \mathrm{t}$ $\mathrm{ha}^{-1}, 30 \mathrm{tha}^{-1}$, and $40 \mathrm{tha}^{-1}$ doses may be as a result of the amount of materials applied. Although, control plots and plots received $10 \mathrm{t} \mathrm{ha}^{-1}$ dose of compost were comparatively lowest in organic matter content. The values recorded for organic matter content under these experiment trials confirming the results reported by previous studies $[6,17]$.

\subsection{Soil Bulk Density}

Soil bulk density is the mass of dry soil per unit of bulk volume, including the air space. It is a measure of weight per unit area, normally expressed as $\mathrm{g} \mathrm{cm}^{-3}$. Low bulk density indicates increased pore space and is indicative of improved soil tilth. Higher bulk density values mean that the soil has less pore space [20]. Previous studies have consistently shown that adding organic matter to soils reduces bulk density. In the case of this study, decline of soil bulk density with increasing dose of applied compost is evident (Tables 2, $3,4 \& 5$ ). The highest bulk density $1.64 \mathrm{~g} \mathrm{~cm}^{-3}$ was obtained in control plots without any compost usage and the least value $1.21 \mathrm{~g} \mathrm{~cm}^{-3}$ in plot treatment with a dose of 40 tons per hectare at the end of fourth crop season (Table 5). The decrement of the bulk density can be attributed to the increasing of organic matter content. Control plots had a higher soil bulk density compared to amended plots. It indicates that compost, added into soil, effects positively the soil structure in a short term period. Brown and Cotton [6] have observed that soil bulk density followed a predictable pattern with decreased bulk density at increasing rate of compost. In this respect, compost increases the portion of macro-pores because of an improved aggregation and stabilization of soil significantly initiated by various soil organisms [21]. On the basis of the present study, various treatments significantly affect the soil bulk density which is in agreement with previous researches $[6,18]$. Similarly, Agbede et al. [12], were found a decrease in soil bulk density by applying chicken manure in a field experiment. Soil bulk density has been decreased using organic fertilizers because of its lower volumetric mass than soil.

\subsection{Soil Total Porosity}

Porosity is a main indicator of soil structural quality. Therefore, its characterization is important in impact evaluation of adding organic matter to soil. Porosity reducing results from the loss of larger pores and the increase of finer pores [22]. Soil porosity and pore size distribution characterize the pore space of the portion of the soil's volume that is not occupied by solid material. The basic character of the pore space governs critical aspects of almost everything that occurs in the soil as the movement of water, air, and other fluids; the transport and the reaction of chemicals; and the residence of roots and other biotas. In the present study, household waste compost application increased total porosity of soil averagely in four crop seasons. Maximum total porosity values were found at last crop season with application of compost elaborated with $70 \%$ of household waste mixed with $30 \%$ of poultry manure compared to the control plots and treated plots with compost elaborated with $100 \%$ of household waste. In general, total porosity increases with compost application dose increasing.

\subsection{Soil Moisture Content}

Increased moisture content was observed in amended soil. The results prove that the soil on the plots with the different doses of the compost showed the increase of the humidity. Household waste composts, applied at these amount had a positive effect on soil moisture retention. Moisture content increases with increasing dose of compost. This means that the response to compost addition varied by application doses. Similar findings have been recorded by Kumar et al. [23] and Zemanek [24]. It is reported that compost application had the greatest effect on soil water holding capacity on coarser textured soils [6]. Angin and Yaganoglu [25] attributed the increase in water-holding capacity values in plot treated with sewage sludge to its high organic matter content.

\subsection{Water Infiltration Rates}

Water infiltration rate may be defined as the maximum capacity at which a given soil at a given time can absorb water and is expressed in $\mathrm{cm} / \mathrm{h}$ or $\mathrm{mm} / \mathrm{h}$. Results from this research show that the compost improved physical properties in soil surface layer as well as total porosity and water infiltration rate (Tables 2, 3, $4 \& 5$ ). The plots that received the composts had a tendency towards higher water infiltration rate when compared to control plots. An increase of water infiltration should be attributed to total porosity augmentation in soils after composts application [26]. These results are often encountered in the literature, since water infiltration is essentially improved by the presence of organic matter and microbiological activity [17]. It is seen that plots treated with $40 \mathrm{t} \mathrm{ha}^{-1}$ of compost, elaborated with $70 \%$ of household waste mixed with $30 \%$ of poultry manure, had the highest infiltration capacity while plots treated with $10 \mathrm{tha}^{-1}$ of compost elaborated with $100 \%$ household waste had the lowest infiltration capacity. This may be attributed to the fact that infiltration rate depends on soil total porosity increased by type and quantity of compost.

\section{Conclusion}

This research indicates that the application of composts obtained from household waste and poultry manure decline 
soil bulk density while increasing soil total porosity, soil moisture content and water infiltration rate in red soils "Terre de barre" in south of Togo. The results revealed that the compost doses of 20,30 and $40 \mathrm{t}^{-1}$ improved proportionally the soil parameters studied. These results suggest that the application of household waste compost at the minimum dose of $20 \mathrm{t} \mathrm{ha}^{-1}$ on red soils "Terre de Barre" in southern Togo could improve significantly their physical properties. It can be deduced that composting is a suitable technology for the recycling of household urban wastes and a mean for soil physical properties improvement.

\section{Acknowledgements}

The authors thank Laboratory of Management, Treatment and Value of Waste, University of Lomé (GTVD/UL) and No Organization Governmental ENPRO (Naturel Ecosystem Clean), for their kind support and cooperation in conducting the study.

\section{References}

[1] Omotayo O. E., Chukwuka K. S., 2009. Soil fertility restoration techniques in sub-Saharan Africa using organic resources. African Journal of Agricultural Research, 4: 144150 .

[2] Lal R., 1986. Conversion of tropical rainforest: Agronomic potential and ecological consequencies. Advances in Agronomy, 39: 173-263.

[3] Lowery B., Swan J., Schumacher T., Jones A., 1995. Physical properties of selected soils by erosion class. Journal of Soils and Water Conservation, 50: 306-311.

[4] Bauer A., Black, A. L., 1992. Organic carbon effects on available water capacity of three soil textural groups. Soil Science Society of America Journal, 56: 248-254.

[5] Haynes R. J., Naidu R., 1998. Influence of lime, fertilizer and manure applications on soil organic matter content and soil physical conditions: a review. Nutrient Cycling in Agroecosystems, 51 (2): 123-137.

[6] Brown S., Cotton M., 2011. Changes in Soil Properties and Carbon Content Following Compost Application: Results of On-farm Sampling. Compost Science and Utilization, 19 (1): 88-97.

[7] Saragoni H., Olivier R., Poss R., 1991. Dynamics and leaching of mineral elements. Agronomie Tropicale, 45 (4): 259-273.

[8] Walkley A., Black I. A., 1934. An examination of method for determining soil organic matter and a proposed modification of the chromic acid titration method. Soil Science, 37: 29-37.

[9] Ibrahim M. M., Mahmoud E. K., Ibrahim D. A., 2015. Effects of vermicompost and water treatment residuals on soil physical properties and wheat yield. International Agrophysics, 29: 157-164.

[10] Anderson J. M., Ingram J. S. I., 1993. Tropical Soil Biology and Fertility. A Handbook of Methods, 2nd Edn., CAB International, Wallingford U.K., pp: 221.
[11] Danielson R. E., Sutherland P. L., 1986. Porosity, in Klue, A. (ed.): Methods of Soil Analysis, Part 1. Physical and Mineralogical Methods. Agronomy Monograph no. 9, 2nd edn. American Society of Agronomy, Madison, pp. 443-461.

[12] Agbede T. M., Ojeniyi S. O., Adeyemo A. J., 2008. Effect of Poultry Manure on Soil Physical and Chemical Properties, Growth and Grain Yield of Sorghum in Southwest, Nigeria. American-Eurasian Journal of Sustainable Agriculture, 2 (1): $72-77$

[13] Reynold W., Elrick D., Youngs E., Amoozegar A., Booltink H. W., Bouma J., 2002. Saturated and field saturated water flow parameters. In: J. H. Dane, G. C. Topp (eds). Methods of soil analysis. Parth 4. Physical methods. SSSA. Madison, Wisconsin, USA, pp 797-878.

[14] Reynolds S. G., 1970. The gravimetric method of soil moisture determination, I: A study of equipment, and methodological problems, Journal of Hydrology, 11: 258-273.

[15] IAEA (International Atomic Energy Agency), 2008. Field Estimation of Soil Water Content: A Practical Guide to Methods, Instrumentation and Sensor Technology. Soil and Water Management \& Crop Nutrition Section, Vienna, Austria $141 \mathrm{p}$.

[16] Shukla A., Panchal H., Mishra M. et al., 2014. Soil moisture Estimation using Gravimetric Technique and FDR Probe Technique: A Comparative Analysis. American International Journal of Research in Formal, Applied \& Natural Sciences (AIJRFANS), 8 (1): 89-92.

[17] Bouajila K., Sanaa M., 2011. Effects of organic amendments on soil physico-chemical and biological properties. Journal of Materials and Environmental Science, 2: 485-490.

[18] Xiuli X., Zhang J., Zhu A., Zhang C., 2016. Effects of longterm (23 years) mineral fertilizer and compost application on physical properties of fluvo-aqauic soil in the North China Plain. Soil \&Tillage Research, 156 (1): 166-172.

[19] Dadashi S., Ghajar Sepanlou M., Mirnia S. K. H., 2019. Influence organic compost compounds on soil chemical and physical properties. International Journal of Human Capital in Urban Management, 4 (1): 15-22.

[20] Mueller L., Schindler U., Mirschel W., Shepherd T. G., Ball B. C., Helming K., Rogasik J., Eulenstein F., Wiggering H., 2010. Assessing the productivity function of soils. A review. Agronomy for Sustainable Development, 30: 601-614.

[21] Liu B., Gumpertz M. L, Hu S., Ristaino J. B., 2007. Long term effects of organic and synthetic soil fertility amendments on soil microbial communities and the development of southern blight. Soil Biology and Biochemistry, 39: 23022316.

[22] Barbera A. C., Maucieri C., Cavallaro V., Ioppolo A., Spagna G., 2013. Effects of spreading olive mill wastewater on soil properties and crops, a review. Agricultural Water Management, 119: 43-53.

[23] Kumar S., Malik R., Dahiya I., 1985. Influence of different organic wastes upon water retention, transmission and contact characteristics of a sandy soil. Australian Journal of Soil Research, 23 (2): 131-136.

[24] Zemanek P., 2011. Evaluation of compost influence on soil water retention. Acta Universitatis Agriculturae et Silviculturae Mendelianae Brunensis, 59 (3): 227-232. 
[25] Angin I., Yaganoglu A. V., 2011. Effects of Sewage Sludge Application on Some Physical and Chemical Properties of a Soil Affected by Wind Erosion. Journal of Agricultural Science and Technology, 13: 757-768.
[26] Weber J. A., Karczewska J., Drozd M., et al.., 2007. Agricultural and ecological aspects of a sandy soil as affected by the application of municipal solid waste composts. Soil Biology and Biochemistry, 39: 1294-1302. 